ENTREPRENEURSHIP AND SUSTAINABILITY ISSUES

ISSN 2345-0282 (online) http://jssidoi.org/jesi/ 2021 Volume 9 Number 2 (December) http://doi.org/10.9770/jesi.2021.9.2(7)
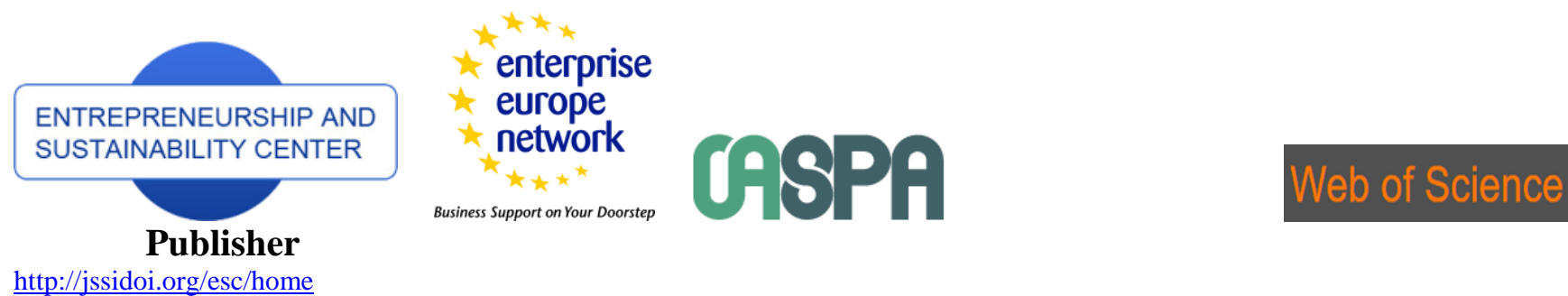

http://jssidoi.org/esc/home

\title{
AN EMPIRICAL INVESTIGATION OF ADOPTION BIG DATA IN HIGHER EDUCATION SUSTAINABILITY
}

\author{
Waleed Mugahed Al-Rahmi ${ }^{1}$, Salem Alkhalaf ${ }^{2}$ \\ ${ }^{1}$ Faculty of Social Sciences \& Humanities, School of Education, Universiti Teknologi Malaysia, UTM, 81310, Skudai, Johor, \\ Malaysia \\ ${ }^{2}$ Department of Computer, College of Science and Arts in Ar Rass, Qassim University, Ar Rass, Saudi Arabia \\ E-mail: ${ }^{1}$ waleed.alrahmi1@gmail.com (Corresponding author)
}

Received 15 July 2021; accepted 16 September 2021; published 30 December 2021

\begin{abstract}
The present research aimed at developing a model on measuring education sustainability, incorporating the literature knowledge management sharing (KMS), innovation as well as adoption of big data (BD) within educational environment. This research hypothesizes that knowledge management sharing influences innovation adoption of BD besides sustainability for learning, while innovation influences adoption of BD besides sustainability in education. It is also hypothesized that BD adoption could be positively connected with education sustainability. The current study adopted a quantitative data gathering approach besides analysis approaches by surveying a total of 811 university undergraduates who were selected by stratified random selection. Learners' feedback was organized along with the four study constructs thus investigated to clarify their education sustainability. Accordingly, the data was analyzed quantitatively by means of Structure Equation Modelling (SEM). Findings demonstrated that knowledge management sharing positively influenced innovation, adoption of big data as sustainability for education. Results also indicate that innovation were negatively significant determinants of adoption of BD but was positively related to sustainability for education. Last, adoption of BD was positively associated to education sustainability. The BD adoption, innovation and knowledge management sharing successfully explained $79.2 \%$ of education sustainability. Implications along with findings of this research were then provided.
\end{abstract}

Keywords: Adoption of Big Data; Knowledge Management Sharing, Sustainability for Education; Structure Equation Modelling (SEM)

Reference to this paper should be made as follows: Al-Rahmi, W.M., Alkhalaf, S. 2021. An empirical investigation of adoption Big Data in higher education sustainability. Entrepreneurship and Sustainability Issues, 9(2), 108-122. http://doi.org/10.9770/jesi.2021.9.2(7)

JEL Classifications: O32, 033

\section{Introduction}

Adoption of Big Data (BD) and Knowledge Management Sharing are regarded innovative technologies for learning in the context of education (Al-Rahmi et al., 2019). Recently, it became easy to produce knowledge and wisdom capable of supporting innovation, innovative services, smart decision making, and new business models from the raw data extracted from humans and machines. The present study investigates the challenges associated with sustainability in education by implementing BD, innovation and knowledge management sharing, and then 


\section{ENTREPRENEURSHIP AND SUSTAINABILITY ISSUES}

ISSN 2345-0282 (online) http://jssidoi.org/jesi/ 2021 Volume 9 Number 2 (December) http://doi.org/10.9770/jesi.2021.9.2(7)

proposed a model capable to measure them. At present, both information and knowledge are highlighted as the source of power instead of land, finance, and capital (Ishikawa and Nakagawa, 2013). This point gives strength to this study which is conducted on BD. It was noticed the usage of BD is not fully utilized by organizations it's still gap (Al-Rahmi et al., 2019). This issue has received little attention from researchers and the reason for this low utilization is still vague (Olszak and Mach-Król, 2018). Thus, this research attempts to investigate the tools used to evaluate the tendency of organizations to utilize BD. How to manage BD and how knowledge management sharing is managed by organizations determine both sustainable competitive advantage and sustainable development (Ngai et al., 2017). The concept of multidisciplinary learning is used to define the group of students belong to different area of specializations or disciplines to come together with the objective of learning and sharing knowledge, while at the same time, applying the knowledge they have gained in real-life settings (Doukanari, Ktoridou, and Epaminonda, 2020). Reason for increasing significance of BD is due to its role in the digital evolution. Examining the different factors influencing the technology of BD adoption in universities is considered timely and critical, especially because the application of BD is still in its infancy. It was also reported that it is both crucial and timely to understand the influence of BD technology adoption, bearing in mind that more than three-quarters of organizations are reported to invest or plan to invest in BD (Gartner, 2016). It was also reported that BD and the various factors influencing its adoption have received little attention (Salleh and Janczewski, 2016; Chen et al., 2016). Therefore, this research proposes the designing such a model that would seek to address this research gap, which can be used by future researches to study the adoption of BD for sustainability in context to education. Ullah et al. (2020) and Ullah et al. (2021) An investigated the features that may influence the behavioral intention of energy experts to implement the distributed ledger technology for the energy management and smart learning environments, concluded that knowledge refers to the high degree of abstraction in the minds of the people. This assumes that knowledge is of a high level in terms of capturing data and information richness and comprehensiveness. Researchers have given knowledge management many definitions. The most significant aspect of knowledge management is knowledge sharing. In spite of the rapid growth in managing, analyzing, this study also looks at the factors behind the adoption of this technology in the different universities, which includes both knowledge management sharing factors and adoption factors. Any improvement in the area of knowledge sharing within any organization are the motivation that encourage the users to adopt such technology (Lam and Lambermont-Ford, 2010). It was found that previous research did not provide sufficient insights into the factors that might motivate knowledge sharing. It is recommended to provide learners with both training and knowledge concerning the problems relevant to sustainability. Such training that takes into consideration the teachers backgrounds and education is of a great importance and they also need to learn and to be trained on sustainability as they are expected to share it with their peers (Martins et al., 2006). Burmeister et al., (2013) highlighted that it is not an easy task for learners to learn about sustainability. Thus, there is a lack of models and framework that is providing examples on how it is to be big data used in organizations is needed (Olszak and Mach-Król, 2018; Kayser et al., 2018). Previous studies on BD mainly concentrate on technical characteristics (for example, technical algorithms and machine learning) as well as the system development (Kwon et al., 2015). Furthermore, in order to maximize the potential and value for the user from many channels, the design of creative learning with a big data approach must emphasize the importance of creating learning on an online basis. In this sense, retrieving huge volumes of data in order to deliver learning activities would provide a wide range of benefits that might lead to novel learning designs (Huda et al., 2017; AlRahmi et al., 2019). Despite the fact that some research has been done on the use of big data in creative teaching, there has been a lack of scholarly attention to explain the learning base of environment to aid in the provision of learning resources (Huda et al., 2017).In this study, four factors were investigated regarding the adoption of BD for education sustainability. Theoretically, several investigations have been performed in the intention of use and adoption of BD field. However, there is a shortage of research that explored the association between innovations, $\mathrm{BD}$ adoption and knowledge management sharing. Consequently, the current research aims to explore BD adoption for education sustainability, whereas no research was empirically performed which utilize such variables to enhance BD adoption successfully in education organizations by governments. 


\section{Theoretical Model and Hypotheses}

A considerable number of competing and complementary models for studying adoption were produced by the research on Innovation adoption. This adoption refers to the adoption of information technology (IT) as well as information systems (IS). Thus, it can be found that most of the research done in the area of adoption used these works as theoretical frameworks. Innovations is considered to be an important concept in context to IT adoption and has been studied extensively by researchers (Puklavec et al., 2014). As a result, four variables influencing big data adoption as a sustainability for education were investigated in the current study: knowledge management sharing (KMS), innovations (IN), adoption of big data (ABD), and sustainability for education (SE), as shown in Figure 1.

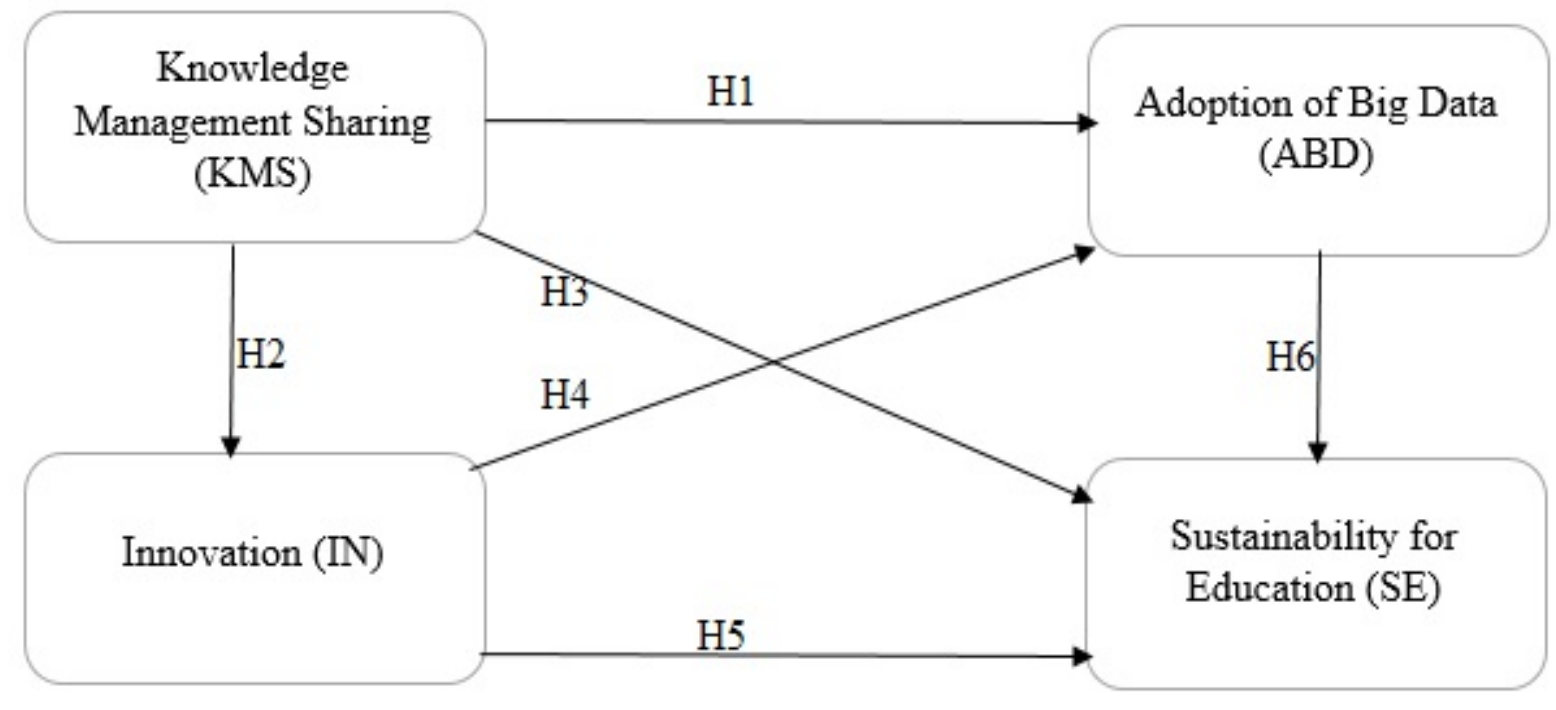

Figure 1. Research Model and Hypotheses Source: Authors

2.1 Knowledge management sharing

Knowledge management is the process of an organization's knowledge and information being created, shared, used, and managed (Girard \& Girard, 2015). Knowledge management is concerned with the process of translating individual knowledge into organizational knowledge, which is accomplished via sharing knowledge. Knowledge management relies heavily on knowledge sharing and the motivators that come with it (Oye et al., 2011).Thus, looking at these factors that motivate people in terms of knowledge sharing is very important for an understanding of knowledge sharing (Oye et al., 2011). A variety of terms and processes are related to knowledge management (KM). As reported by Cockrell and Stone (2010), KM includes essential terms such as acquirement of knowledge, knowledge exchange, and knowledge transference. Big data and knowledge management are critical components in sustaining and enhancing a variety of academic outcomes and procedures. As a result, big data and knowledge management are critical in any organization, and educational learning is no exception (Erickson \& Rothberg, 2015).Therefore, this research uses the knowledge management sharing as a factor affect an innovation, big data adaptation and educational sustainability in higher education.

\subsection{Innovations}

'Innovation may thus be described as the process of having unique ideas and insights that have value, and then executing them such that they are accepted and utilized by substantial numbers of people,' says Rick Miller, President of Olin College of Engineering (2011, p. 2). Performing such innovations takes time as it is adjusted a number of times to suit the desired objective. It is simply a better product, practice, program, or process than the 


\section{ENTREPRENEURSHIP AND SUSTAINABILITY ISSUES}

ISSN 2345-0282 (online) http://jssidoi.org/jesi/ 2021 Volume 9 Number 2 (December) http://doi.org/10.9770/jesi.2021.9.2(7)

original one. When such an innovation is adopted many times, it becomes the new trend. Many learning and teaching contexts are witnessing innovations which are built on standard practices by introducing new standards to be followed for the purpose of achieving a better result in terms of learning. Innovation is proven to be the main reason behind the success of USA (Zeihan, 2014). Individuals contribute their own knowledge in order to attain improved innovation levels as organizations do not have the capability of creating knowledge without individuals (Ordaz et al., 2011). As highlighted by Kamasak and Bulutlar in (2010), the researchers declared that when ideas and notions are shared amongst groups, the first group's ideas are perceived to be innovative and novel to other groups. Consequently, one group's ideas are viewed to be new to others and vice versa. The ability of students to adopt innovation as part of problem solving and critical analytical adoption, is affected with their ability to develop along with share knowledge, and that is well justified. This is because innovation comes from knowledge transference and exchange (Sáenz et al., 2009). Based on above studies, knowledge and knowledge sharing are indispensable to achieve high levels of innovation performance. The existing literature demonstrates that knowledge and innovation are directly related to one another. While knowledge is considered as a means to represent both technological innovations as well as process, new knowledge is the direct product of new innovation. Innovations can be of several categories and therefore, how organizations attain them is significantly dependent on knowledge sharing processes used by both individuals and groups. Consequently, both knowledge and knowledge distribution process may be indispensable to achieve high levels of innovation performance. MoreoverBig data analytic process may be upgraded to help learners in discovering information effectively in line with their interests and requirements, in terms of technical competency in the method to manage the learning style built into the strategies and innovation (Huda et al., 2017). Furthermore, in terms of the extent to which the model reference of virtual learning approach is expected to contribute to expanding the extent of pedagogy and technology skill to support the initiative way of teaching and learning process in the higher education context, the model reference of virtual learning approach is expected to contribute to expanding the extent of pedagogy and technology skill to support the initiative way of teaching and learning process in the higher education context (Huda et al., 2017). Therefore, this research uses an innovation as a factor affect big data adaptation and educational sustainability in higher education.

\subsection{Adoption of Big Data}

Big data, as defined by Drigas and Leliopoulos (2014), is defined as the expansion of mobile networks, cloud computing, and enormous volumes of data, with a focus on bigger scaled datasets with high speed and diverse patterns that are beyond the control of traditional data management. Sigman et al. (2014) characterize it as having two characteristics: 1) huge amounts of data in a real-time stream; and 2) varied degrees of data structure, ranging from personal information to social networking resources. Bihl et al. (2016) focuses more on the distinctions from regular data, describing the concept as the accumulation of data beyond consumers' processing capacity, causing them to get overwhelmed .BD is characterized by having high-volume, excessive levels of variety and rate to involve certain technology as well as analytical techniques for their transformation into value (Mauro et al., 2016). Having a closer look at the issues that may impact the BD adoption by organizations is considered a great value, especially such organizations that are rapidly investing and investing in BD. Thus, BD use in higher education received scant attention and previous research in this domain has emphasized significantly on its development across various disciplines and key areas (Daniel, 2015). BD utilization in higher education has many advantages such as inspiring teachers' inquiry, discovering methods for defining improved education contexts and providing chances to scientifically examine educational activities (Mor et al., 2015). Avramides et al., (2015) also add that this utilization can result in enabling educators to reflect upon their education practice and its influence on the outcomes of learning. Studies pertaining to the implementation of BD within the educational sector have demonstrates its application through variety of techniques such as analytics, augmented reality (AR), virtual reality (VR), etc. (Butson and Daniel, 2017). According to Daniel (2015), in the field of the effective utilization of $\mathrm{BD}$ in education, both collaboration and access are considered major issues. Educational research can be developed through granting educational institutions with data accessibility and collaborative learning (Al-Rahmi et al., 2020; Alamri et al., 2020). Research heavily referred to these frameworks to investigate innovations, 


\section{ENTREPRENEURSHIP AND SUSTAINABILITY ISSUES}

ISSN 2345-0282 (online) http://jssidoi.org/jesi/ 2021 Volume 9 Number 2 (December) http://doi.org/10.9770/jesi.2021.9.2(7)

including the adoption of BD by organizations (Nam et al., 2015; Agrawal, 2015; Sun et al., 2016). Salleh and Janczewski (2016) study have also presented a comprehensive analysis on BD security. This is because BD is considered to be one of the most significant innovations in terms of information technology (IT) (Nguyen, and Petersen, 2017). In connection with the adoption of BD, IT adoption in a variety of innovations has proven positively influenced by IT expertise (Nam et al., 2015). Big data allows for the creation of learning information about student performance and learning methods (Al-Rahmi et al., 2020; Al-Rahmi et al., 20219). Using big data, a variety of tools and assessments may be used to measure student behaviors and the efficacy of instructors' instruction in a learning environment where they engage with one another (Hwang, 2019). Big data may also help external stakeholders who are interested in the institutional efficacy in the competitive higher education market comprehend the intricate higher education system (Hwang, 2019). Big data has consequences for learning, evaluation, and research in higher education institutions, as well as a map of developing potentials in the form of various data sources and modes, such as conventional formats, brand new visualization tools, and the new value of interdisciplinary education (Cope and Kalantzis, 2016). In today's world, he has combined the form of data sources with the need for a self-regulating and long-term system to represent the resources' dependability and validity (Wassan, 2015). As a result, big data is used in this study as a factor affecting educational sustainability in higher education.

\subsection{Sustainability for Education}

Education is a tool to aid in the process of sustainable development, and education sustainability encompasses all types of educational concepts, actions, and processes that are appropriate for fostering individual and/or communal contributions to sustainable development (Hoffmann and Siege, 2018). Sustainability is defined as the process of adopting of new methodologies and modernizing of old educational system within the educational domain. It is based on values along with competitive principles as well as on a predatory view of the world. This term is considered far more complicated than sustainable development (Gadotti, 2010). The term sustainability means critical ecological cosmovision and is considered a major player in development that obtains harmony among humans, development along with the Earth understood as Gaia. Certain challenges might be posed when approaching sustainability in cultural diversity. Also, there is limited time allocated for other subjects such as sustainability since graduate and postgraduate courses are heavily loaded with mandatory subjects. In order to reach sustainable development, lifelong learning is considered essential due to the fact that learning these subjects through the different stages of education is important. Hands-on science experiments, demonstrations and participating in public debates are examples of sustainability concepts inserted in such curricula (Martins et al., 2006).

\section{Research Methodology}

Two specialists were referred for the questionnaire's content evaluation. Before proceeding to the data collection, a research permit was acquired from a public university for research purposes. For this research, the targeted population were undergraduate and postgraduate learners. A questionnaire had been designed for this research, which had been used to target the intended population. The researcher included both opened ended and closed ended questions to gain insights on educational sustainability, BD, KMS, and innovation. There were 24 questions (items) that were designed to collect background information from 811 respondents, see appendix. Thus, questionnaire elements pertaining to population by a 5-point Likert scale. Participants were responsible for responding to the questions related to educational sustainability, $\mathrm{BD}$, innovation, and KMS. The data was analyzed using the most recent version of IBM's Social Sciences Statistical Package (SPSS). Structural Equation Modelling was also used to evaluate the data (SEM-Amos). Construct validity evaluation, convergent validity, and discriminant validity analysis were all conducted using the former. Finally, structural modeling (Hair, Sarstedt, Ringle, and Mena) was completed (2012). 


\section{ENTREPRENEURSHIP AND SUSTAINABILITY ISSUES}

ISSN 2345-0282 (online) http://jssidoi.org/jesi/ 2021 Volume 9 Number 2 (December) http://doi.org/10.9770/jesi.2021.9.2(7)

3.1 Sample Characteristics and Data Collection

Only 856 of 940 hand-delivered surveys were returned, resulting in a 91.1 percent return rate. Following the discovery of 18 incomplete surveys, a total of 838 questionnaires were analyzed using the most recent SPSS version. This revealed another 27 surveys, 12 of which had missing data and 15 of which were outliers. As a result, the final sample size was 811 surveys. According to Hair et al. (2012), this method is critical for determining the right sample size since outliers can have a substantial impact on the accuracy of the results.

\subsection{Measurement Instruments}

The elements in the constructs were changed to meet the goal of guaranteeing content validity. The questionnaire was divided into two portions, as previously stated. The participants' demographic information was obtained in the first section. The second portion consisted of 24 items taken from Davis (1989) and Venkatesh and Bala (2008) measurements. As a result, the final and third part, which was built using IDT, had 18 items modified from research (Davis, 1989; Moore and Benbasat, 1991; Karahanna et al., 2002).

\subsection{Data Analysis}

The majority of the respondents were males, who made up $432(53.3 \%)$ of the sample, whereas $379(46.7 \%)$ of the sample comprised of females. The vast majority of the respondents $662(81.6 \%)$ were in between the ages 21 to $24.90(11.1 \%)$ of the participants were between the ages 18 to $20.45(5.5 \%)$ of the participants belonged to 25 to 20 , whereas the remaining $14(1.7 \%)$ of the participants were above the age of 30 . Based on the level of education, the vast majority of the participants were undergraduate study and made up $331(48 \%)$ of the sample. $31.6 \%$ of the participants belonged to postgraduate master level, whereas the remaining $27.6 \%$ of the participants were $\mathrm{PhD}$ students. In terms of specialization, the majority of the participants belonged to science and technology and thus, made $50.4 \%$ of the sample. $35.3 \%$ of the participants were engineering students, and the remaining $14.3 \%$ of the participants were social science students.

\section{Result Analysis}

The Cronbach's Alpha reliability coefficient for the components in the research model that have an influence on knowledge management sharing, innovation, and BD adoption for education sustainability was 0.907. Three criteria were used in the discriminant validity examination. The index of the variables should not be more than 0.8. (Hair et al, 2021). The AVE value for each construct should not be less than 0.5. The AVE square for each concept should be greater than the factors inter construct correlations (IC) (Fornell and Larcker, 1998). The factor loadings in confirmatory factor analysis (CFA) should not be less than 0.7. Cronbach's alpha should never be less than 0.7. (Hair, Ringle, and Sarstedt, 2012). The composite reliability (CR) must also meet the same criteria, with a value of no less than 0.7 .

4.1 Measurement Model Analysis

AMOS 23 was utilized to analyze the data in this investigation. Confirmatory factor analysis (CFA) and structural equation modeling (SEM) were also employed in this study. The researchers utilized reliability, discriminant validity, and convergent validity. The concept of unidimensionality was also employed. According to Hair et al. (2012), model approximation can be accomplished using techniques such as the chi-square/degree of freedom, fit index (CFI), comparative incremental fit index (IFI), normed chi-square, fit index (NFI), relative fit index (RFI), Tucker-Lewis coefficient (TLI), the parsimonious goodness of fit index (PGFI), the root mean square error of approximation (RMSEA), and the root mean-square error of app (RMR). The goodness-of-fit indices were used to evaluate the model for education sustainability over innovation, knowledge management sharing, and BD, as shown in Table 1. Figure 2 depicts a framework for educational sustainability based on knowledge management, innovation, and business development. 
Table 1. Summary of Goodness Fit Indices for the Measurement Model.

\begin{tabular}{|c|c|}
\hline Measures and accepted value & Results \\
\hline Chi-square $(\chi 2): \leq 3.5$ to $0 \& \rho>.01$ & $1602.429 / 246$ \\
\hline Normed Chi-square $(\chi 2):>1.0 \&<5.0$ & 6.514 \\
\hline Root-Mean Residual (RMR): Close to 0 & .034 \\
\hline Normed Fit Index (NFI): $\geq 0.90$ & .967 \\
\hline Relative Fit Index (RFI): $\geq 0.90$ & .951 \\
\hline Incremental Fit Index (IFI): $\geq 0.90$ & .985 \\
\hline Tucker Lewis Index (TLI): $\geq 0.90$ & .971 \\
\hline Comparative Fit Index (CFI): $\geq 0.90$ & .985 \\
\hline $\begin{array}{l}\text { Root-Mean Square Error of Approximation (RMSEA): } \\
\text { for a good fit }<0.10 \& \text { for a very good fit }<0.05\end{array}$ & .043 \\
\hline
\end{tabular}

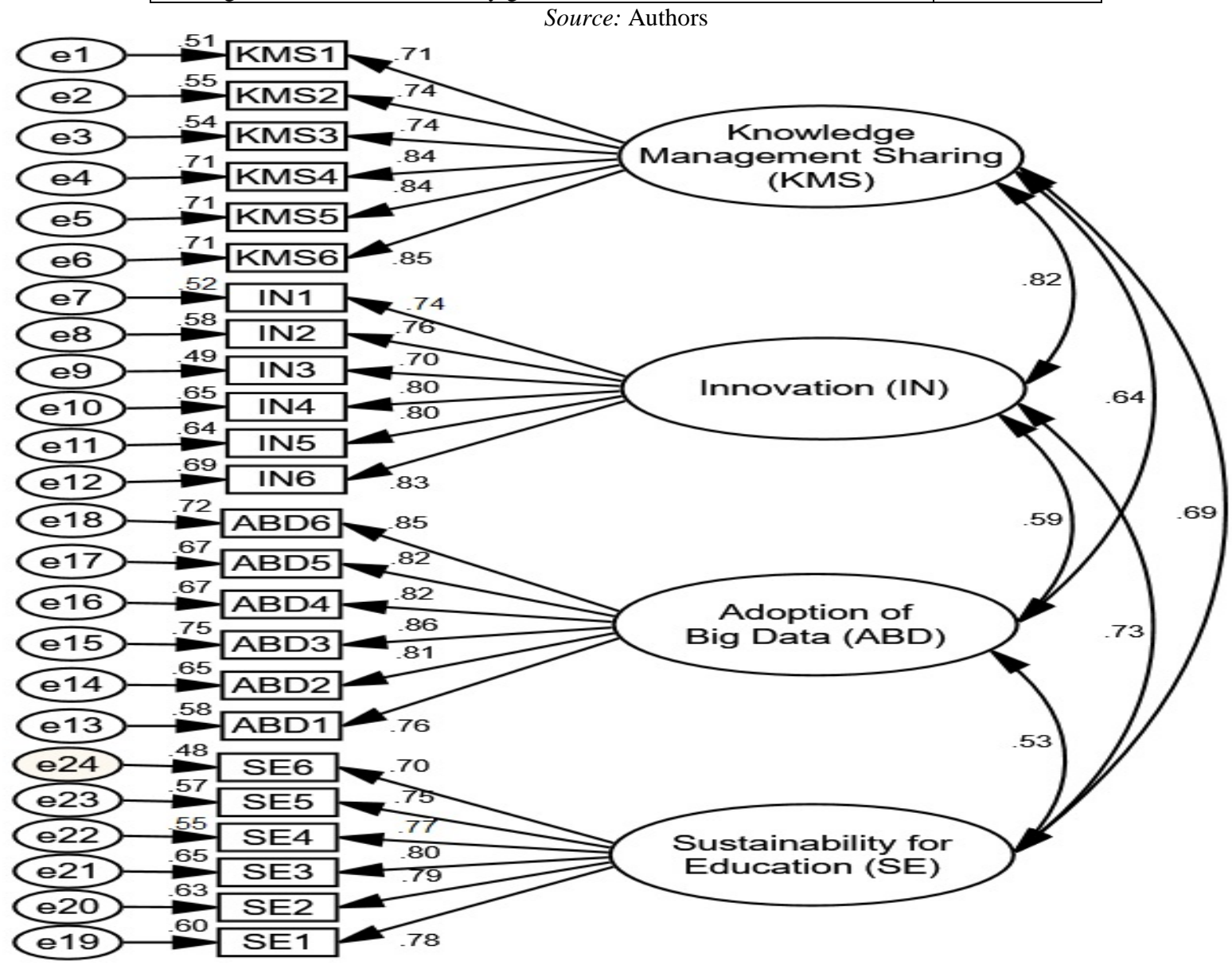

Figure 2. Measurement Model Source: Authors

\subsection{Measures Model Validity and Reliability}

The size fluctuations among a concept and its values in combination with other concepts are determined using this form of validity (Bagozzi and Yi, 1998). Discriminant validity was found to be favorable across all concepts from this standpoint. This is due to the fact that the value was more than 0.5. (cut-off value). 0.001 was discovered to be the value of o. (Fornell and Larcker, 1981). Items' connections in any two supplied concepts must not be over the square root of the average variance shared by them in one construct, according to Hair et al., (2012). The 
subsequent values of composite reliability (CR) and those of Cronbach's Alpha (CA) were found to be either equal or above the value of 0.7. The value of AVE was equal or above 0.5. This demonstrates that the factor loadings (FL) were found to have a significant relationship (Hair et al., 2012; Fornell and Larcker, 1981). The results of measurement model are further discussed in other sections of the study. The composite reliability (CR) results demonstrates that its values exceeded 0.7 and were from 0.887 to 0.932 . The Cronbach's alpha (CA) value also exceeded 0.7 and was in the range of 0.891 to 0.941 . The value of AVE was in the range of 0.597 to 0.651 , which was above 0.5. All of these values were found to be greater than their required value. (Hair et al., 2012; Fornell and Larcker, 1981). See table 2 and 3.

Table 2. Validity and reliability for the Model

\begin{tabular}{|l|c|c|c|c|c|c|c|}
\hline \multicolumn{1}{|c|}{ Factors } & KMS & IN & ABD & SE & AVE & CR & CA \\
\hline Knowledge Management Sharing (KMS) & 0.911 & & & & 0.651 & 0.915 & 0.941 \\
\hline Innovation (IN) & 0.534 & 0.920 & & & 0.597 & 0.887 & 0.912 \\
\hline Adoption of Big Data (ABD) & 0.423 & 0.514 & 0.899 & & 0.611 & 0.919 & 0.927 \\
\hline Sustainability for Education (SE) & 0.521 & 0.498 & 0.501 & 0.907 & 0.637 & 0.932 & 0.891 \\
\hline
\end{tabular}

Table 3. Factor loading

\begin{tabular}{|c|c|c|}
\hline Factors & Items & Factor Loadings \\
\hline \multirow{6}{*}{$\begin{array}{l}\text { Knowledge } \\
\text { Management } \\
\text { Sharing (KMS) }\end{array}$} & KMS1 & 0.71 \\
\hline & KMS2 & 0.74 \\
\hline & KMS3 & 0.74 \\
\hline & KMS4 & 0.84 \\
\hline & KMS5 & 0.84 \\
\hline & KMS6 & 0.85 \\
\hline \multirow{6}{*}{ Innovation (IN) } & IN1 & 0.74 \\
\hline & IN2 & 0.76 \\
\hline & IN3 & 0.70 \\
\hline & IN4 & 0.80 \\
\hline & IN5 & 0.80 \\
\hline & IN6 & 0.83 \\
\hline \multirow{6}{*}{$\begin{array}{l}\text { Adoption of Big } \\
\text { Data (ABD) }\end{array}$} & ABD1 & 0.85 \\
\hline & ABD2 & 0.82 \\
\hline & ABD3 & 0.82 \\
\hline & ABD4 & 0.86 \\
\hline & ABD5 & 0.81 \\
\hline & ABD6 & 0.76 \\
\hline \multirow{6}{*}{$\begin{array}{l}\text { Sustainability for } \\
\text { Education (SE) }\end{array}$} & SE1 & 0.70 \\
\hline & SE2 & 0.75 \\
\hline & SE3 & 0.77 \\
\hline & SE4 & 0.80 \\
\hline & SE5 & 0.79 \\
\hline & SE6 & 0.78 \\
\hline
\end{tabular}

4.3 Structural Model Analysis

The path modelling analysis has been used in this research for modelling education sustainability in context to research model in relation of KMS, BD, and innovation. Referring to the model, the findings were compared and presented in the hypothesis testing discussion. This was followed by the second phase, the hypothesis identified were analyzed using CFA analysis on structural equation modelling (SEM) as illustrated in Figure 3. 


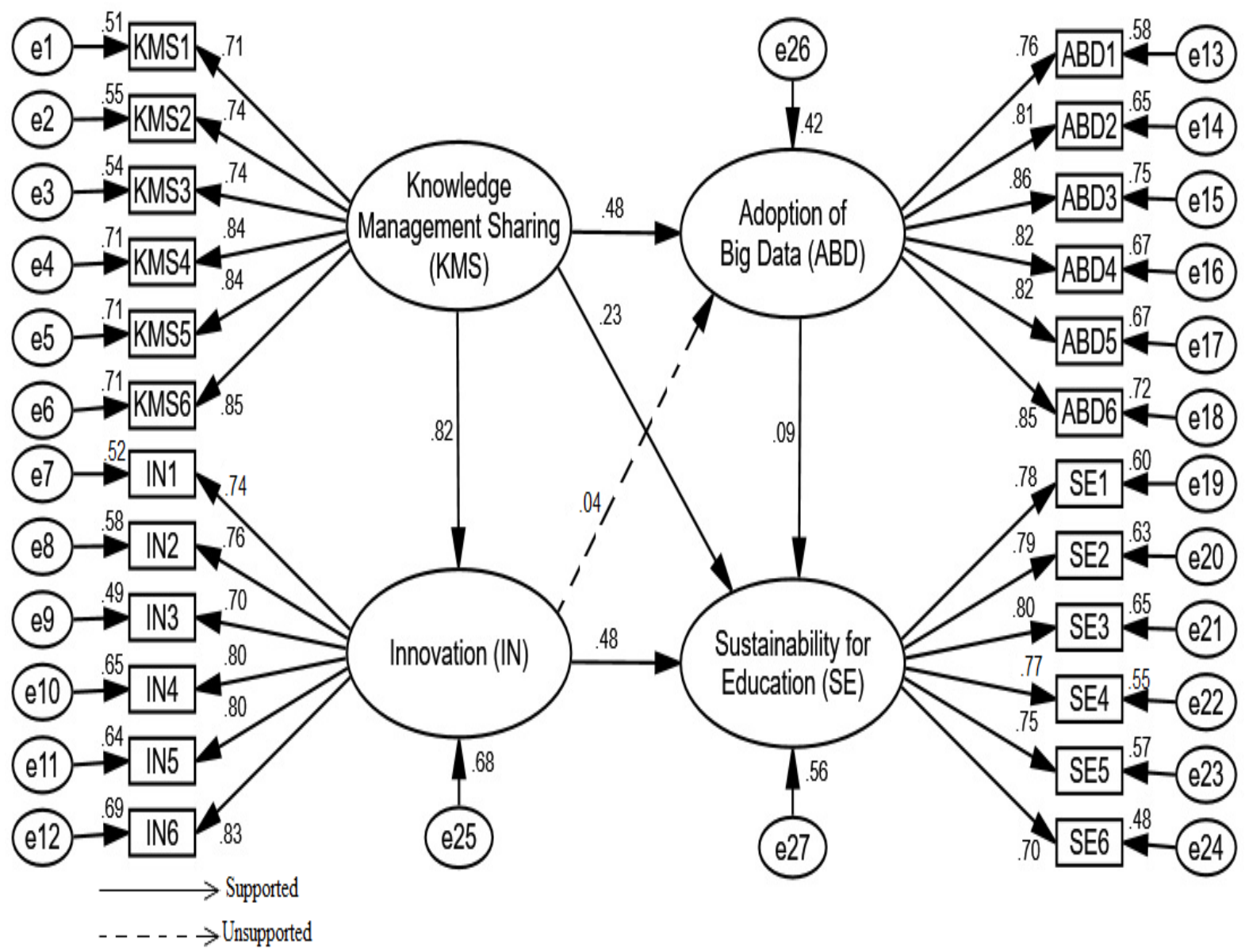

Figure 3. Results for the Proposed Path Model (Estimate)

Source: Authors

Figure 3 shows that five of the six hypotheses were proved, while one was rejected as a consequence of the data analysis. Table 4 shows the results of the model's statistical analysis.

Table 4. Hypothesis testing results of structural model

\begin{tabular}{|l|l|l|l|l|l|l|l|l|}
\hline H & Independent & Relationship & Dependent & Estimate & S.E & C.R & P & Result \\
\hline H1 & KSM & $\longrightarrow$ & ABD & .431 & .066 & 6.551 & .000 & Supported \\
\hline H2 & KSM & $\longrightarrow$ & IN & .818 & .040 & 20.617 & .000 & Supported \\
\hline H3 & KSM & $\longrightarrow$ & SE & .196 & .059 & 3.311 & .000 & Supported \\
\hline H4 & IN & $\longrightarrow$ & ABD & .029 & .024 & 1.199 & .279 & Unsupported \\
\hline H5 & IN & $\longrightarrow$ & SE & .410 & .059 & 6.998 & .000 & Supported \\
\hline H6 & ABD & $\longrightarrow$ & SE & .086 & .039 & 2.198 & .028 & Supported \\
\hline
\end{tabular}

Source: Authors

The relationship between knowledge management sharing and BD adoption yielded the following data $(\beta=0.431$, $\mathrm{t}=6.551, \mathrm{p}<0.001)$ for the first hypothesis. As a result, the first hypothesis has been established and is being tested. The connection between knowledge management sharing and creativity is positive $(\beta=0.818, t=20.617, p<0.001)$, 


\section{ENTREPRENEURSHIP AND SUSTAINABILITY ISSUES}

ISSN 2345-0282 (online) http://jssidoi.org/jesi/ 2021 Volume 9 Number 2 (December) http://doi.org/10.9770/jesi.2021.9.2(7)

according to the second hypothesis. Knowledge management sharing and educational sustainability show a positive connection $(\beta=0.196, \mathrm{t}=3.311, \mathrm{p}<0.001)$. The third hypothesis is similarly favorable. The link between BD uptake and innovation is not supported $(\beta=0.029, \mathrm{t}=1.199, \mathrm{p}<0.001)$. Hypothesis number four is rejected since it is negative. The fifth hypothesis demonstrates that there is a link between educational sustainability and creativity, indicating that the relationship is beneficial. Finally, data show that BD adoption is linked to education sustainability $(\beta=0.086, \mathrm{t}=2.198, \mathrm{p}<0.001)$, implying that the sixth hypothesis is likewise confirmed and supported.

\section{Implications and Discussion}

The goal of this study was to take a fresh look at the BD model by combining it with knowledge management to see what factors influence its long-term viability and acceptance in education. This research was a more sophisticated attempt at incorporating knowledge management sharing into a business development adoption paradigm. The relationships between four innovative qualities, including invention, BD adoption, knowledge management sharing, and education sustainability, were identified using the methodology presented for this study.Despite the fact that we are witnessing the early stages of BD. At the present time, as reported in both research and media, many organizations around the world are making use of BD. In area of knowledge management sharing, BD is seen as a double-edged sword. The negative side is represented by the idea or assumption that such knowledge can make knowledge management sharing obsolete. On basis of phenomenological and human sociological aspects of knowledge, it has been instrumental in dealing with technological foregrounds as previously it was a fundamental challenge pertaining to knowledge management. Remaining as a dis-unified field has been identified as one of the major problem associated with knowledge management. BD is expected to bring such unity. BD and knowledge management are seen as two important fields that can have mutual lessons and collaboration opening the door wide for future research. Innovation is considered to be the process of creating, adopting, and implementing novel ideals, programs, products, services, or policies within the organization (Kamasak and Bulutlar, 2010). The statistical analysis results related to the Table 4, shows that all hypothesis have been proven with the exception of one hypothesis (H4), the association among innovations and adoption of BD use. It demonstrates that innovations and adoption of BD have a negative relationship. This is in contrast to the earlier research (Nguyen and Petersen, 2017; Nam et al., 2015; Mor et al., 2015). This research has demonstrated that KMS and innovation, adoption of BD use and education sustainability have a positive relationship. Results also revealed that innovation positively influence sustainability of education, but innovation negatively impact adoption of BD use, which in turn influence adoption and sustainability for education purposes. The findings also have supported that innovations and knowledge management sharing in context to BD for education sustainability. The findings of this research is compatible with previous researches that have bene conducted in this domain. They have verified that knowledge management sharing had significant positive effects on innovations, adoption of BD use and sustainability of education (Oye et al., 2011; Gartner, 2016; Butson and Daniel, 2017; Nguyen, and Petersen, 2017). On the other hand, it was observed that innovation had no significant negative effects on adoption of BD, but had significant positive effects on sustainability of education (Zeihan, 2014; Daniel, 2015). The various sources of knowledge in an organization can be controlled by knowledge management by being captured, identified and processed (Rajpathak and Narsingpurkar, 2013). There is a huge amount of valuable structured and untraditional data beyond the transactional ones used by organizations. Data that is available can be processed and structured to gain important information, which can be used by organizations to aid their decision-making process, enhance their efficiency, and increase their profitability (Rajpathak and Narsingpurkar, 2013). Many social tools such as Twitter, Facebook, Google+ accounts and Linked-in are available in the hands of young people who use them in their everyday life. Young people also use different tools of social media or websites for certain purpose such as uploading photographs through the use of Flickr, having opinion mining or sentiment analysis through semantria.com or crowd sourcing through the use of Amazon.com. All the above-mentioned activities are all examples of BD use. In recent times, information over the internet is available abundantly. Furthermore, several data sources are available for smart 


\section{ENTREPRENEURSHIP AND SUSTAINABILITY ISSUES}

ISSN 2345-0282 (online) http://jssidoi.org/jesi/ 2021 Volume 9 Number 2 (December) http://doi.org/10.9770/jesi.2021.9.2(7)

and intelligent devices such as sensors, smart devices, RFIDs, social media networks, medical records, and cameras. On the other hand, both the web as well as the web-based social networking (BD) have significantly increased in speed and simplicity, therefore, social networking platforms likewise permit information sharing among the public, collaborative learning, and engagement, (Alalwan et al., 2019). Faculty must determine BD use in addition to offering instructional materials that would improve technology learning among the students. Furthermore, findings suggest that faculty must explain how technology assists students, in addition to how it benefits them regarding BD study in order to achieve other learning goals. Learners who perceived that the knowledge management sharing and innovations would benefit them acquire BD adoption for education sustainability. Similarly, this study requires three practical pieces of evidence. First, knowledge management sharing effects innovation empirical evidence, adoption of BD use and sustainability of education. Second, empirical evidence of innovation effects BD and technologies adoption uses and sustainability of education. The third empirical evidence of adoption of BD use can directly affect sustainability of education. Substantia contribution has been made based on research model in context to educational learning (Al-Rahmi et al., 20201a; Al-Rahmi et al., 20201b; Sayaf et al., 2021). Based on the findings of this research, the following research implications have been identified:

- To adopt BD for learning, supervisors and lecturers can assist the learners through responding to the questions/queries of learners and support for knowledge sharing, which will enhance learners learning concerns in addition to improve researcher's skill in relation to research.

- Institution of higher education are encouraged to enroll learners to be familiar with the use of $\mathrm{BD}$ in regard to learning courses based on their own desires rather than forcing them to do so.

- Resources and Technology both are significant issues of interest in learners ' attitude regarding BD use and behavioral intent to BD adoption use for education sustainability.

No research is conducted without certain limitations. For example, the study sample size in this study was restricted to one university. Consequently, findings might not be able to disclose the performance of private universities, militaries, or school educators. Another drawback of this study is that it relies solely on questionnaires. Because the study lacked qualitative data, it was based on students' impressions, which may differ from instructors' perceptions. Furthermore, the study did not look at differences between academic disciplines. It is advised that future studies be duplicated in other states.

\subsection{Conclusion and Future Work}

The impact of KMS on BD adoption and innovation has been studied in this research and, which is out to be positively correlated to education sustainability, has been proven and supported in the current study. The findings also showed that innovation influences education sustainability. Research model use in examining knowledge management sharing, innovations and adoption of big data for education sustainability was additionally endorsed by the findings. Consequently, this study makes significant contribution to existing literature pertaining to KMS, innovation and adoption of big use for education sustainability. Considering the significance that learners intend to use BD for education sustainability, further future research must take into consideration constructing guidelines for instructors in relation to BD based learning other disciplines and areas. Future research should also consider the role of educators and other stakeholders in context to BD based learning environments. While this research indicates that learners might be rather positive with it, facilitators and constraints must be explored. Comparisons of this study with studies conducted in other countries with reference to this research can also enhance the outcomes of the study as it can offer a wide perspective on the area under investigation. 


\section{ENTREPRENEURSHIP AND SUSTAINABILITY ISSUES}

ISSN 2345-0282 (online) http://jssidoi.org/jesi/ 2021 Volume 9 Number 2 (December) http://doi.org/10.9770/jesi.2021.9.2(7)

\section{References}

Agrawal, K.P. (2015). Investigating the Determinants of Big Data analytics (BDA) Adoption in Asian Emerging Economies, Patna: Chandragupt Institute of Management. https://doi.org/10.5465/ambpp.2015.11290abstract

Alalwan, N., Al-Rahmi, W. M., Alfarraj, O., Alzahrani, A., Yahaya, N., \& Al-Rahmi, A. M. (2019). Integrated Three Theories to Develop a Model of Factors Affecting Students' Academic Performance in Higher Education. IEEE Access, 7, 98725-98742. https://doi.org/10.1109/access.2019.2928142

Alamri, M. M., Almaiah, M. A., \& Al-Rahmi, W. M. (2020). The role of compatibility and task-technology fit (TTF): On social networking applications (SNAs) usage as sustainability in higher education. IEEE Access, 8, 161668-161681. https://doi.org/10.1109/access.2020.3021944

Al-Rahmi, A. M., Al-Rahmi, W. M., Alturki, U., Aldraiweesh, A., Almutairy, S., \& Al-Adwan, A. S. (2021a). Exploring the Factors Affecting Mobile Learning for Sustainability in Higher Education. Sustainability, 13(14), 7893. https://doi.org/10.3390/su13147893

Al-Rahmi, A. M., Shamsuddin, A., Alturki, U., Aldraiweesh, A., Yusof, F. M., Al-Rahmi, W. M., \& Aljeraiwi, A. A. (2021b). The Influence of Information System Success and Technology Acceptance Model on Social Media Factors in Education. Sustainability, 13(14), 7770. https://doi.org/10.3390/su13147770

Al-Rahmi, W. M., Alzahrani, A. I., Yahaya, N., Alalwan, N., \& Kamin, Y. B. (2020). Digital communication: Information and communication technology (ICT) usage for education sustainability. Sustainability, 12(12), 5052. https://doi.org/10.3390/su12125052

Al-Rahmi, W. M., Yahaya, N., Aldraiweesh, A. A., Alturki, U., Alamri, M. M., Saud, M. S. B., ... \& Alhamed, O. A. (2019). Big data adoption and knowledge management sharing: An empirical investigation on their adoption and sustainability as a purpose of education. IEEE Access, 7, 47245-47258. https://doi.org/10.1109/access.2019.2906668

Avramides, K., Hunter, J., Oliver, M., \& Luckin, R. (2015). A method for teacher inquiry in cross curricular projects: Lessons from a case study. British Journal of Educational Technology, 46(2), 249-264. https://doi.org/10.1111/bjet.12233

Bagozzi, R.P., Yi, Y., \& Nassen, K.D. (1988). Representation of measurement error in marketing variables: Review of approaches and extension to three-facet designs. Journal of Econometrics, 89(1-2), 393-421. https://doi.org/10.1016/s0304-4076(98)00068-2

Bihl, T. J., Young II, W. A., \& Weckman, G. R. (2016). Defining, understanding, and addressing big data. International Journal of Business Analytics (IJBAN), 3(2), 1-32. https://doi.org/10.4018/978-1-5225-7501-6.ch004

Burmeister, M., Schmidt-Jacob, S., and Eilk, I. (2013). German chemistry teachers' understanding of sustainability and education for sustainable development an interview case study. Chem. Educ. Res. Pract. 14, 169-176. https://doi.org/10.1039/c2rp20137b

Butson, R.J., \& Daniel, B.K. (2017).The Rise of Big Data and Analytics in Higher Education. In The Analytics Process (pp. 127-140). Auerbach Publications, 2017. https://doi.org/10.1201/9781315161501-5

Chen, Y., Chen, H., Gorkhali, A., Lu, Y., Ma, Y., \& Li,L. (2016). Big data analytics and big data science: a survey. Journal of Management Analytics, 3(1), 1-42. https://doi.org/10.1080/23270012.2016.1141332

Cockrell, R.C., \& Stone, D.N. (2010). Industry culture influences pseudo-knowledge sharing: a multiple mediation analysis. Journal of Knowledge Management, 14 (6), 841-857. https://doi.org/10.1108/13673271011084899

Cope, B., \& Kalantzis, M. (2016). Big data comes to school: Implications for learning, assessment, and research. Aera Open, 2(2), 2332858416641907. https://doi.org/10.1177/2332858416641907

Daniel, B. (2015). Big Data and analytics in higher education: Opportunities and challenges. British journal of educational technology, 46(5), 904-920. https://doi.org/10.1111/bjet.12230

Davis, F.D. (1993). User Acceptance of information technology: system characteristics, user perceptions and behavioural impacts. International Journal of Man-Machine Studies, 38, 475- 487. https://doi.org/10.1006/imms.1993.1022

Doukanari E., Ktoridou D., \& Epaminonda E. (2020). Multidisciplinary and Multicultural Knowledge Transfer and Sharing in Higher Education Teamworking. In IEEE Xplore proceedings of EDUCON 2020 - IEEE Global Engineering Education Conference "Engineering 


\section{ENTREPRENEURSHIP AND SUSTAINABILITY ISSUES}

ISSN 2345-0282 (online) http://jssidoi.org/jesi/ 2021 Volume 9 Number 2 (December) http://doi.org/10.9770/jesi.2021.9.2(7)

Education Through Student Engagement", Porto, Portugal, April 27-30, $2020 . \quad$ pp. $1836-1843$. https://doi.org/10.1109/educon45650.2020.9125401

Drigas, A. S., \& Leliopoulos, P. (2014). The use of big data in education. International Journal of Computer Science Issues (IJCSI), 11(5), 58. https://www.ijcsi.org/papers/IJCSI-11-5-1-58-63.pdf

Erickson, S., \& Rothberg, H. (2015). Big data and knowledge management: establishing a conceptual foundation. Leading Issues in Knowledge Management, 2, 204. https://books.google.com.sa/books?hl=en\&lr=\&id=SCdsCwAAQBAJ\&oi=fnd\&pg=PA204\&dq=Big+data+and+knowledge+management: + establishing $+a+$ conceptual+foundation\&ots=WQHPMpiDHL\&sig=8iGDG-

ReGrZtEOSEnbrly29lrf4\&redir_esc=y\#v=onepage\&q=Big\%20data\%20and\%20knowledge $\% 20$ management $\% 3 \mathrm{~A} \% 20$ establishing $\% 20 \mathrm{a} \%$ 20conceptual $\% 20$ foundation $\& \mathrm{f}=$ false

Fornell, C., \& Larcker, D.F. (1998). Evaluating structural equation models with unobservable variables and measurement error. Journal of Marketing Research, 39-50. https://journals.sagepub.com/doi/10.1177/002224378101800104

Gadotti, M. (2010). Reorienting education practices towards sustainability. Journal of Education for Sustainable Development, 4(2). 203211. https://journals.sagepub.com/doi/abs/10.1177/097340821000400207?.journalCode=jsda

Gartner, A. (2016). Gartner Survey Shows More Than 75 Percent of Companies Are Investing or Planning to Invest in Big Data in the Next Two Years [Online] Available at: http://www.gartner.com/newsroom/id/3130817

Girard, J.P., \& Girard, J.L. (2015). Defining knowledge management: Toward an applied compendium, Online Journal of Applied Knowledge Management. 3(1), 1-20. https://www.iiakm.org/ojakm/articles/2015/volume3_1/OJAKM_Volume3_1pp1-20.pdf

Hair, J.F., Sarstedt, M., Ringle, C.M., \& Mena, J.A. (2012).An assessment of the use of partial least squares structural equation modeling in marketing research. Journal of the Academy of Marketing Science, 40(3), 414-433. https://link.springer.com/article/10.1007/s11747-011$\underline{0261-6}$

Hoffmann, T., \& Siege, H. (2018). What is Education for Sustainable Development (ESD). Human Development, 1(8), 1-6. https://esdexpert.net/files/ESD-Expert/pdf/Was_wir_tun/Lehr-\%20und\%20Lernmaterialien/What_is_Education_for_Sustainable_Development.pdf

Huda, M., Haron, Z., Ripin, M. N., Hehsan, A., \& Yaacob, A. B. C. (2017). Exploring innovative learning environment (ILE): big data era. International Journal of Applied Engineering Research, 12(17), 6678-6685. https://www.ripublication.com/ijaer17/ijaerv12n17_53.pdf

Hwang, Y. (2019). Adoption of Big Data in Higher Education for Better Institutional Effectiveness. American Journal of Creative Education, 2(1), 31-44. https://doi.org/10.20448/815.21.31.44

Ishikawa, A., \& Nakagawa, J. (2013). An Introduction to Knowledge Information Strategy. From Business Intelligence to Knowledge Sciences; World Scientific: London, UK, ISBN 978-981-4324-42-7, 2013. https://doi.org/10.1142/7924

Karahanna, E., Evaristo, J., \& Srite, M. (2002). Methodological Issues in MIS Cross-Cultural Research. Journal of Global Information Management, 10(1), 48-55. https://doi.org/10.4018/978-1-59140-144-5.ch011

Kayser, V., Nehrke, B., \& Zubovic, D. (2018). Data Science as an Innovation Challenge: From Big Data to Value Proposition. Technology Innovation Management Review, 8(3). https://doi.org/10.22215/timreview/1143

Kwon, T.H., Kwak, J.H., \& Kim, K. (2015). A study on the establishment of policies for the activation of a big data industry and prioritization of policies: Lessons from Korea. Technological Forecasting and Social Change, 96, 144-152. https://doi.org/10.1016/j.techfore.2015.03.017

Lam, A., and Lambermont-Ford, J.P. (2010). Knowledge sharing in organizational contexts: A motivation-based perspective. Journal of Knowledge Management, 14(1), 51-56. https://doi.org/10.1108/13673271011015561

Martins, A.A., Mata, T.M., \& Costa, C.A. (2006). Education for sustainability: challenges and trends. Clean Technologies and Environmental Policy, 8(1), 31-37. https://doi.org/10.1007/s10098-005-0026-3

Mauro, A.D., Greco, M., \& Grimaldi, M. (2016). A formal definition of Big Data based on its essential features. Library Review, 65(3), 122-135. https://doi.org/10.1108/lr-06-2015-0061 


\section{ENTREPRENEURSHIP AND SUSTAINABILITY ISSUES}

ISSN 2345-0282 (online) http://jssidoi.org/jesi/ 2021 Volume 9 Number 2 (December) http://doi.org/10.9770/jesi.2021.9.2(7)

Miller, R. K. (2011, May). How do you recognize and cultivate potential innovator?. Paper presented at Olin College. Retrieved from https://www.olin.edu/sites/default/files/how do you recognize and cultivate potential innovators - may 2011.pdf

Moore, G.C., \& Benbasat, I. (1991). Development of an instrument to measure the perceptions of adopting an information technology innovation. Information Systems Research, 2(3), 192-222. https://doi.org/10.1287/isre.2.3.192

Mor, Y., Ferguson, R., \& Wasson, B. (2015). Learning design, teacher inquiry into student learning and learning analytics: A call for action. British Journal of Educational Technology, 46(2), 221-229. https://doi.org/10.1111/bjet.12273

Nam, D., Kang, D., \& Kim S. (2015). Process of big data analysis adoption: Defining big data as a new IS innovation and examining factors affecting the process. Hawaii, Hawaii International Conference on Systems Sciences, 2015. https://doi.org/10.1109/hicss.2015.569

Ngai, E.W., Gunasekaran, A., Wamba, S.F., Akter, S., \& Dubey, R. (2017). Big data analytics in electronic markets. Electron. Mark. 27, 243-245. https://doi.org/10.1007/s12525-017-0261-6

Nguyen, T., \& Petersen, T.E. (2017). Technology adoption in Norway: organizational assimilation of big data. (Master's thesis). https://openaccess.nhh.no/nhh-xmlui/handle/11250/2455449

Olszak, C. \& Mach-Król, M. (2018). A Conceptual Framework for Assessing an Organization "es Readiness to Adopt Big Data. Sustainability, 10(10), 3734. https://doi.org/10.3390/su10103734

Oye, N.D., Salleh, M., \& Iaha, N.A. Knowledge sharing in workplace: Motivators and demotivators. International Journal of Managing Information Technology, 3(4), 71-84, 2011. https://doi.org/10.5121/ijmit.2011.3406

Puklavec, B., Oliveira, T., \& Popovič, A. (2014). Unpacking business intelligence systems adoption determinants: An exploratory study of small and medium enterprises. Economic and Business Review, 16(2), 185-23. https://doi.org/10.15458/2335-4216.1278

Rajpathak, T., and Narsingpurkar, A. (2013). Knowledge from big data analytics in product development. TCS white paper. https://www.semanticscholar.org/paper/Managing-Knowledge-from-Big-Data-Analytics-in-

Rajpathak/fc95a536777c5bc54cef8399fb93a10803fb94e2

Sáenz, J., Aramburu, N., \& Rivera, O. (2009). Knowledge sharing and innovation performance: A comparison between high-tech and lowtech companies. Journal of Intellectual Capital, 10(1), 22-36. https://doi.org/10.1108/14691930910922879.

Salleh, K., \& Janczewski, L. (2016). Technological, organizational and environmental security and privacy issues of big data: A literature review. Procedia Computer Science, 100, 19-28. https://doi.org/10.1016/j.procs.2016.09.119

Sayaf, A. M., Alamri, M. M., Alqahtani, M. A., \& Al-Rahmi, W. M. (2021). Information and Communications Technology Used in Higher Education: An Empirical Study on Digital Learning as Sustainability. Sustainability, 13(13), 7074. https://doi.org/10.3390/su13137074

Sigman, B. P., Garr, W., Pongsajapan, R., Selvanadin, M., Bolling, K., \& Marsh, G. (2014). Teaching big data: Experiences, lessons learned, and future directions. Decision Line, 45(1), 10-15. http://statlit.org/pdf/2014-Sigman-Teaching-Big-Data-DSI.pdf

Sun, S., Cegielski, C.G., Jia, L., \& Hall, D.J. (2016). Understanding the Factors Affecting the Organizational Adoption of Big Data. Journal of Computer Information Systems, 1-11. https://doi.org/10.1080/08874417.2016.1222891

Ullah, N., Alnumay, W. S., Al-Rahmi, W. M., Alzahrani, A. I., \& Al-Samarraie, H. (2020). Modeling cost saving and innovativeness for blockchain technology adoption by energy management. Energies, 13(18), 4783. https://doi.org/10.3390/en13184783

Ullah, N., Mugahed Al-Rahmi, W., Alzahrani, A. I., Alfarraj, O., \& Alblehai, F. M. (2021). Blockchain Technology Adoption in Smart Learning Environments. Sustainability, 13(4), 1801. https://doi.org/10.3390/su13041801

Venkatesh, V., \& Bala, H. (2008).Technology Acceptance Model 3 and a research agenda on interventions .Journal of Decision Sciences, 39, 2, pp. 273-315. https://doi.org/10.1111/j.1540-5915.2008.00192.x

Wassan, J. T. (2015). Discovering big data modelling for educational world. Procedia-Social and Behavioral Sciences, 176 , 642-649. https://doi.org/10.1016/j.sbspro.2015.01.522

Zeihan, P. (2014).The Accidental Superpower: The Next Generation of American Preeminence and the Coming Global Disorder, Twelve Hachette Book Group, New York, NY. https://www.amazon.com/Accidental-Superpower-Generation-AmericanPreeminence/dp/1455583685 


\section{ENTREPRENEURSHIP AND SUSTAINABILITY ISSUES}

ISSN 2345-0282 (online) http://jssidoi.org/jesi/ 2021 Volume 9 Number 2 (December) http://doi.org/10.9770/jesi.2021.9.2(7)

Waleed Mugahed AL-RAHMI

ORCID ID: https://orcid.org/0000-0002-0980-7439

\section{Salem ALKHALAF}

ORCID ID: https://orcid.org/0000-0002-5900-6752

Make your research more visible, join the Twitter account of ENTREPRENEURSHIP AND SUSTAINABILITY ISSUES: @Entrepr69728810

Copyright (C) 2021 by author(s) and VsI Entrepreneurship and Sustainability Center

This work is licensed under the Creative Commons Attribution International License (CC BY).

http://creativecommons.org/licenses/by/4.0/

(c) (i) Open Access 